Professor Angela Thody was one of the participants in an EU funded research project to produce pan-European training materials for school principals. The leader of the team was Professor Petros Pashiardis of the Open University in Cyprus and the other participants were Professor Zoe Papanoum of Aristotle University of Thessaloniki, Greece and Professor Olof Johannson of Umea University, Sweden. The project produced a CD of training materials (also in this repository) and this article. It was published in International Journal of Education Management, 2007, 21 (1) pp. 37-53.

For more information about the author www.angelathody.com

Professor Angela Thody, Centre for Education Research and Development University of Lincoln, Brayford Campus, Lincoln, LN6 7TS

Phone: 01522886071

Email: athody@lincoln.ac.uk/ angelathody450@hotmail.com

Keywords: Europe; schools; principals; headteachers; Greece; Sweden; Cyprus; England; principals' training; principals' selection; centralisation.

\title{
School Principal Preparation In Europe
}

Thody, A. with Pashiardis, P., Johansson, O. and Papanoum, Z.,

\section{ABSTRACT}

This article centres on Cypriot, English, Greek and Swedish selection and training of principals. This was part of a 2001-2003 European Union (EU) funded study which created a distance learning CD ROM for principals. We analysed and compared national education systems and principals' selection and training using documents, focus groups, principals’ interviews and an international seminar. The most centralised systems of Greece and Cyprus had less principal preparation, and more government involvement in principal selection, than the less centralised Sweden and England. The extent of training was perceived to matter less in successful principalship than selecting the right people although it was felt that even a good leader can be improved through training and principals were concerned about their lack of formal training. 


\section{KEY WORDS}

Leadership training; England; Cyprus; Sweden; Greece. 


\section{School Principal Preparation In Europe}

\section{Introduction}

This article reports part of a 2001-2002 European Union (EU) funded study of school principals' preparation in England ${ }^{1}$, Greece, Cyprus ${ }^{2}$ and Sweden, led by $\mathrm{xxx}$ (name deleted for blind review process0. This initiative is part of many movements to European integration, described in the first part of this article concerning our research provenance. Our research techniques, discussed in the article’s second section, were exploratory because conceptual frameworks for cross-cultural studies in education leadership are only in their infancy (Dimmock and Walker, 1998; Richmon and Allison, 2003) and because comparative research on which we might model our project, is rare though examples are now emerging (International Studies in Educational Administration, 31 [2] passim).

The subsequent sections of this article are from material collected for the funded research whose outcome had to be distance learning materials for school leaders’ preparation. Creating such transnational resources is regarded as very challenging (Van den Brandon and Lambert, 1999). To cope with this, we decided to focus our group investigations on assessing how far our attitudes were similar on various major topics of educational leadership issues. These eventually became the topics in the CD-ROM masters degree module for school principals in any European country $^{3}$ which we designed as the outcome of this project.

This article concentrates on one of these topics, principal preparation systems. We began by investigating what similarities there were in our national education systems to see if there is sufficient in common amongst our schools' needs to make feasible any common training for leaders and to ascertain what leaders might find 
useful to help them to cope with individual national circumstances. The outcome of this comparative review of our four countries' education systems is summarised in the third section of this article.

Following this, we reviewed what training principals currently receive in our countries and interviewed principals to find out their views on how they had been selected and trained for principalship. This is reported in sections four and five of this article.

Our reflections on how to train leaders inevitably raised questions for us about the roles of leaders which led to a section in the CD ROM on Successful Leadership. Moving on from this led us to develop a new concept of Mediated Leadership as a compromise amongst differing attitudes to democracy and hierarchy in school organisation. Finally, throughout the project, we discussed, reflected and analysed the CD ROM topic, European education leadership - towards consensus on a definition. We conclude this article with a brief flavour of this elusive topic.

Readers from outside of Europe will find it valuable to compare and contrast their leadership preparation systems with ours. In the four countries in this study, what is offered to putative principals extends along a continuum from very little at one end, to what could almost be described as 'overkill' at the other. Similarly, our education systems range through extensive, moderate and slight centralisation. One of these types should offer some similarities to your own states, countries or provinces and thus offer you insights for transferable ideas or for approaches you might want to avoid. The authors welcome your reactions. Our team had a fascinating journey learning about each other's systems; we anticipate that you too will enjoy the travel. 


\section{Research provenance: European integration}

There is extensive literature on school principalship preparation but this is largely dominated by texts from, and about, North America, Australasia and the United Kingdom or is related to each of the four countries separately (Pashiardis, 1995, 1997; Pashiardis and Orphanou, 1999). In Europe, there have been scattered efforts to develop the field but no attempt to explore a possible European alliance, or joint approach to leadership selection and training. The prospects seemed gloomy in the light of experiences in other education professions (see Budge's views on the inspectorate for example, 1999) but important as the EU expands into a possible United States of Europe.

The project began as ten of the EU countries launched a joint currency in 2002 and concluded as first drafts of a European Constitution were being prepared in 2003. This article is contemporaneous with the EU's expansion with ten more members. All these developments were part of an integration which began in 1947 when the USA's Marshall Plan offered aid to rebuild a war-destroyed European economy provided that the nations of Europe collaborated to decide how to use that aid. From that impetus six countries formed the European Coal and Steel Community (ECSC), the European Atomic Community (EURATOM) and the European Economic Community (EEC) in the 1950s.

The four countries in this research have been active in European integration ${ }^{4}$ but not in those first movements towards the European Union of today of which all are now members (England, 1973; Greece, 1981; Sweden, 1995; Cyprus, 2004). As European integration proceeded, groups from many different professions began to meet at governmental levels to produce common policies, standards, qualifications 
and processes. Everything seems to have been included in these integration efforts from the sizes of fish tins, meat tins and little metal bottle tops, to medical degrees, tractor tyres, human rights, clothing sizes, legal sovereignties and the terminology for chocolate bars. Almost everything that is, except for education and schooling systems.

Education remains one of the responsibilities and rights reserved to the nation states in the EU but the EU has gradually found a way into some aspects of education through its social policy duties ${ }^{5}$. To encourage such education developments by learning from each other's educational practices, non-governmental organisations of enthusiasts have brought together educational leaders and researchers as in the British Education Leadership, Management and Administration Society (BELMAS), the Cyprus Educational Administration Society (CEAS) (both starting in the 1970s) and the European Forum on Educational Administration (EFEA) (Lafond, 1995). Such organisations have encouraged a focus on principals' preparation. Thus developments in our own field and in wider European integration motivated this research project.

\section{Research Techniques}

The spine of the project was four focussed discussion groups, two day meetings of four university researchers, one from each nation ${ }^{6}$. These occurred at three month intervals over twelve months, each in a different country. Between meetings, researchers collated primary and secondary documentary data on their national preparation systems according to frameworks negotiated at the early meetings, exchanged this through email and conducted semi-structured interviews with principals in each country to obtain practitioner perspectives. The project culminated with a seminar at an international conference when delegates from North America and from many European countries discussed the results. 
Part of the first group meeting in Sweden in 2001 was tape recorded and later transcribed verbatim, edited, analysed and reviewed at subsequent meetings. To accord with European traditions, the final 2003 seminar was arranged as a RomanoGreek symposium, accompanied by wine and grapes. This, and the excellent chairmanship of Professor Paul Bredeson, may account for the enthusiastic participation of the audience. This session was videoed, transcribed verbatim, edited and analysed.

Pan-European educational leadership research is so exploratory that there was no earlier research on which we might model our processes. We were not even sure that we had common words through which we might consult others through, for example, surveys. We needed to develop both our ideas and the semantics for our field of study. We had not worked as a group before and each of us had not previously met at least some of the other participants so we needed time to get to know each other. The joint development of ideas through four consecutive focussed groups seemed an ideal way to do this. Fuelled with coffee and chocolates, the talk flowed readily and maintained a tight orientation. The conversations provided,

'individual perspectives in an environment where judgements are not automatically expressed ... a relational and participatory way of thinking ... Each participant ... .has the responsibility to push the understandings and learnings of a group ... to a shared basic perception, to a greater sensitivity in perceiving subtle meanings around us’ (Ackerman, 1998, 19). 
These discussions certainly met Morgan’s (1988) conditions for focus groups that 'participants have something to say and feel comfortable enough to say it' (cited in Cohen, Manion and Morrison, 2000:288).

We deviated from Kreuger's criteria for focus groups (1998) since we were five (later four) rather than six participants but Morgan (1988) sees the norm as any number between four and twelve. We did not use a single facilitator as Kreuger recommends (op cit); instead we all operated as participant facilitators. This was ideal in these circumstances where we had no previously prescribed topics to cover and it was from the group's interactions that the subjects emerged. It is such interactions that are the heart of focussed group research and which keep 'the meeting open ended but to the point' (Cohen et al, 2000:288)

Semi-structured interviews were conducted by this articles’ authors, with an opportunity sample of two principals from state (public) primary (elementary) and secondary schools in each country (one in Sweden) in early 2002. It was not possible to obtain exactly comparable samples and interview methods but the data did provide vital practitioner insights. The team records its most grateful thanks to the principals who agreed to be interviewed. Some wished to remain anonymous; others did not. We respected their respective wishes in our reports below. It is possible that their wishes were a reflection of their education systems: English and Swedish whose 'success' might be deemed relative to their individual schools, did not request anonymity; Greek and Cypriot principals whose ‘success’ could be seen as fitting in with a centralized system, did request anonymity.

The principals were first contacted by telephone, email or letter. Once an initial and positive contact had been made this was followed up as soon as possible by an outline of the questions and the purpose for the interviews. Five interviews took 
place in the principals' offices though the English interviews were by telephone. The Swedish interview was by email. The school library housed one of the Greek interviews. All interviews were semi-structured around the same themes but we found that different national experiences and languages meant that we did not always obtain comparable data. What was important in one country, did not gain a mention in another. Interviewees were assured that they could raise additional issues and could express plainly his/her opinions and feelings. In England and Greece, each interview lasted about one hour, in Cyprus, ninety minutes. The timings were by mutual agreement between interviewees and interviewer.

The Cypriot and Greek conversations were taped and transcribed. The English interviewer typed the notes to a word processor while the telephone interview was in progress using a hands free, loud speaker telephone. There was some clipping of words and the noise of the word processor keys sometimes inhibited hearing. Edited transcripts were made available to the principals involved for such revisions, additions or excisions as they might wish to make. The email interview exchanges with Sweden were automatically checked by the interviewee in the exchange of emails.

\section{Our national education systems}

In seeking to understand how far the roles of principals varied amongst our four countries, we focussed particularly on the extent of their autonomy because European educational systems since the 1970s, have experimented with various forms of school self-government. Greece and Cyprus are very centralised systems in all aspects. All England's schools are self-managing businesses but with strong central government curricular control. Sweden comes between these two extremes with less extensive self management than that in England, less extensive centralisation than that in Greece and 
Cyprus but greater local government responsibilities for education than in the other three countries.

In all four countries, school leadership has become more complex and demanding as curricular demands have grown, parental, government expectations and demands for greater school effectiveness have been raised and there have been changes in attitudes to how children and adults learn. For Sweden's and England's principals, accountability and competition have extended: local site-based management has made principals directly responsible for school quality and performance and parents and community leaders in both Sweden and England have become more powerful on school councils and governing bodies.

All four countries have national curricula for compulsory schooling (nine years in Sweden and Greece, ten in Cyprus, eleven in England). This is least prescriptive in Sweden but the principals' roles in all four countries can be described as they are in Sweden. First, principals guarantee a nationally equivalent education; every school is required to meet the national standards, regardless of where it is located and its working conditions. Secondly, principals guarantee pupils’ and parents’ rights and that their schools' education meets national quality standards. Thirdly, principals develop the educational activities at their schools.

In Cyprus, Greece and England the dominance of the national curriculum is reinforced by state-set examinations and, in Greece and Cyprus, by state required textbooks. The examinations are most extensive in England with national standards and tests of these at 7,11 and 13; public examinations at 16 and 18 are set by national, but independent, examination boards. Cypriot and Greek schools set their own examinations until the national tests at the end of secondary education. England's principals are particularly concerned about their schools' examination results as these 
are published in the media with schools ranked in national league tables. School inspectors have great powers in England where their reports can close down schools deemed to be failing their pupils. In Cyprus, inspectors grade principals which then determines their promotion to inspector. Greece and Sweden have a more advisory approach in their school inspections.

In running the business of the school, England's principals are far more autonomous than their counterparts in the other three countries. This is encouraged through the appointment system; England's principals are chosen, employed and can be dismissed by the individual governing bodies of their schools. Sweden's principals owe allegiance to their appointing municipalities while Greek and Cypriot principals are centrally appointed. Further, England's schools are each financially autonomous and principals must manage their own budgets. This does not apply in any of the other three countries although finance for all our countries' schools is state provided (through various combinations of local and central governments).

Principals have to respond to their staff as well as to governments. Traditions of teacher autonomy are strong in Sweden so that the principals can often be pressed between the rocks of central and local government demands and those of the teachers. In Cyprus, it is the teacher's union which provides the countervailing force. In Greece and England, teachers are less powerful but in England, it is the principal who appoints, promotes and disciplines the teachers for his/her school; in the other three countries, central or local governments hold these responsibilities. Teacher certification is regulated by state agencies in all four countries as is the content of preservice teacher training. Principals are responsible for appraising their staff though this ranges from a regulated annual system in England to a much less organised one in Cyprus. 


\section{Leadership preparation overview}

The differing degrees of centralisation in our respective systems seem reflected in leadership preparation provision. Countries in which principals' roles are mainly to administer state policies, with little autonomy allowed, have less training for principalship than those where leaders have to manage their schools more individually. Hence, only as recently as the late 1990s, have Greek principals been offered optional short, in-service training courses, run by the Ministry of Education. In addition some principals have chosen voluntarily to attend relevant courses provided by the National School of Public Administration. Cyprus has no leadership preparation programmes though the Ministry of Education provides one-year management courses. Cyprus has university courses in educational administration but those opting to take them are unlikely to become principals until many years after course completion because of the seniority of service rules. Sweden provides regional preparation once principals have been selected and educational administration can be taken as a component of university degrees. England's principals have a national college, national pre-service, induction and in-service courses and qualifications and pre-service national principal assessment processes; for almost forty years there have been university educational administration degrees and school district short courses for both pre-service and in-service principals. In none of the four countries is formal preparation compulsory though it is likely that the state's national certification will soon be compulsory in England.

The varying extents of formal preparation are reflected in the requirements for principals' activities. The duties and responsibilities of Cypriot school principals are prescribed by the Ministry of Education and Culture and of Greek principals by 
education law. England has an extensive list of nationally agreed principals' competency descriptors. Sweden has a short list of agreed roles.

Our first focussed discussion group in 2001 showed how much our views about the extent of training needed by principals were influenced by our own systems even where we were critical of these. You will, however, sense, in the extracts from the discussions below, a tentative consensus emerging about the respective values of training, experience and personality in the effective preparation of leaders.

\section{Speakers In the following transcript, identified as}

1,2,3,4 - will be identified after

blind review

2: $\quad$ Of course excellency in principalship is not a matter of mere training.

3: $\quad$ [But] the good leaders that I have seen in Cyprus ... had no training whatsoever in educational administration. I don’t think I would argue, however. that they were 'born to lead'. All I am saying is that they can exist..

2: $\quad$ They have a strong educational philosophy ... Highly important is their theoretical and political thinking which means how they envisage the next generation as citizens of the twenty first century ... they can inspire people.

3: $\quad$ And they are good observers of behaviour. When I asked school principals in Cyprus about their preparation ... [they] ... said, "Well I learnt through the mistakes of others, that is not to repeat them” when 
they were teachers and watching their own principals. Some said "I was inspired by an excellent principal I had and I'm complimenting that and taking it a bit further.” None of those I interviewed had any formal training.

4: $\quad$ It seems to me that in Cyprus and Greece, you are where England was in the 1970s, when we could say there were good leaders in schools but there wasn't any training then. Training began with various, nonaccredited short courses during the 1970s. Gradually, this expanded to post-graduate degree programmes, mentoring and post-appointment training courses in the 1980s and early 1990s. By the end of the 1990s, there was national preparation, post-appointment and professional development ... .So ... do we really need this training? It's a very pertinent question since obviously you are currently developing training for educational leaders in Greece and Cyprus, and we’ve come together as a group specifically to develop our various national approaches into potentially Europeanised and European-wide training. Sweden and England have ever growing provision. Are we just assuming that all this training is really needed? We all appeared to agree that there is a 'something' in leadership that can’t be put in by training.

3: $\quad$ Perhaps we need training because we have a thousand principals and maybe only ten of them spontaneously have the visioning abilities we described above as necessary for good educational organisations? ...

2: $\quad$ Yes but how can one person acquire all of this educational philosophy ... ? It is a long term process. It cannot be acquired in six months training or one year ... 
1: $\quad$... we have had a strong tradition in Sweden for the last twenty years that we learn from our practice. Basically ... those in ... leadership positions, come together to reflect and think about what they have done and what can be learnt from this ... [but] there will be a limit to the learning we can acquire from our practice ... There is another arena ... [of] philosophies and models for education [and a] third ... - research which involves studying the practices of others as well as our own ... From these three arenas combined comes new knowledge ... Good educational leaders realise this because they are learners themselves..

4: I'd agree with that absolutely. In England we have strong traditions of practitioner research which have largely emerged from action research methodology. From the late 1990s, our government supported practitioner research financially. School principals can obtain from the Department for Education and Skills, a ‘best practice’ grant to do some studies in their own schools and to go and research comparisons in other schools in England and abroad ...

\section{Principal preparation systems in Cyprus, England, Greece and Sweden.}

Our next task was to open our minds to possibilities from each other's country's principal preparation systems. A summary of the information we gathered is given below. All four systems showed different ways of tackling the dilemma of ensuring that principals adhere to their central governments' expectations of schooling while recognising that principalship is essentially a role in which the incumbent must be able to operate effectively alone. 
In Cyprus, principals, deputy principals and heads of departments at primary and secondary level receive compulsory one-year, weekly, in-service training provided by the Pedagogical Institute. These courses concern management duties and responsibilities which the Ministry of Education and Culture deems important for school administration. In general, there is no requirement for any certificated external education (e.g. Masters Degrees) in order for someone to be appointed to any administrative position and there are no short courses run by consultants or local education authorities. The assumption underlying these practices in Cyprus, is that good teachers should become good managerial principals and do not need leadership preparation (Pashiardis, 1997).

Decisions on promotion to principal are made by the Cypriot Educational Service Commission which supposedly has regard to years of service, worth and excellence as a teacher and diplomas, degrees or other academic credentials in order to create the list from which it chooses new assistant principals and principals. However, since all candidates have much the same academic qualifications and because almost everybody is regarded as an excellent teacher, the only significant differentiation comes from counting years in service - the seniority system which takes little account of competency or suitability for principalship. There is also evidence that those appointed as principals belong to a particular political party and principals, academics and UNESCO have criticised this system for producing a demoralised profession and stagnating schools (Drake et al, 1997, pp.26, 56-58; Pashiardis and Ribbins, 2000). This results in a system where the average age of principals on first appointment is around 55 years. They are then faced with the prospect of compulsory retirement at age 60 . 
And how is the appointment made? A few years ago, once a candidate had the necessary points his/her name appeared on the list to be promoted without applying. Now candidates must apply and face an interview conducted by the Education Service Commission. The candidate is informed of the school to which he/she is appointed only very shortly before taking up post so there is no time to prepare.

Once appointed, Cypriot principals essentially sink or swim alone. The Ministry of Education offers a few induction seminars but these are not found helpful. Typically new principals are sent to a rural school for a period of two years before being brought into one of the towns. They usually stay in a specific school for between two and four years, depending upon the length of time they have until retirement.

England's school principals are likely to be veterans of specialist qualifications in educational leadership, from a university post-graduate Masters or Doctoral programme, and/or central government’s accredited preparation (National Professional Qualification for Principals - NPQH) or in-service courses and from many non-award bearing courses from business or local education authority (LEA) specialists (Tomlinson et al, 1999; Brundett, 2001). All but a very few ${ }^{7}$ primary and secondary school principals will have had extensive previous experience as teachers who have progressed through various levels of leadership responsibilities, invariably spending time as a middle manager (e.g. Key Stage Co-ordinator in primary schools, a Head of Department or Year in secondary schools) and then in a school's Senior Management Team as a Deputy or Acting Head before gaining a principalship.

A National College for School Leaders was inaugurated in 2000 thus forming the apex of a hierarchy of national competency organised tests and standards for educationalists' accreditation (TTA, 1997) through which the majority of principals 
now pass. This comes after around twenty years of a slow movement to nationalised, compulsory, competency-led and accredited training schemes for potential and principals (Thody, 1997; Brundrett, 1999) which accelerated suddenly after 1997. This fitted in with the both needs of principals running competent businesses within central guidelines and with comparable competency based training developments in other professions.

Universities developed postgraduate programmes in educational leadership from the mid-1970s onwards, beginning with MSc degrees in education management and then extending to MBAs as the business orientation of school leadership grew. Doctorates in educational leadership commenced in the early 1990s. These courses are not standardised across the country. University degrees remain a significant, but minority pursuit as preparation for headship.

All these degrees offer a wide education in both the theories and practices of leadership in order to produce reflective practitioners (Schon, 1987) through action learning and a research orientation. Most are course-work assessed and this course work is self-selected topics of relevance to a participant's own needs in education.

Those commencing the road to headship since 2002 will almost certainly undertake the NPQH. This includes a period at an assessment centre when experts test their abilities and advise on suitability for headship. If approved, putative heads will undertake the NPQH which concerns management competencies and skills in strategic direction and accountability, modules on learning and teaching, people and relationships and effective management of financial and physical resources (Bush, 1998). Its aim is to create accountable principals capable of improving pupils’ achievements. 
After finishing, or during completion of. the NPQH, candidates apply for headships advertised in the national press. Each school's governing body ${ }^{8}$ selects, interviews and appoints the principal. Neither local (school district) nor central, governments have any power over who is appointed to a school headship.

Once appointed, all new heads receive a funds allocation to spend on their training over two years as each principal deems best for his/her own needs, e.g. on short or degree courses, on mentoring or consultancy. LEAS also provide induction training so it is available nationally but its content will vary in different areas.

In the late 1990s, a national refresher programme for experienced principals was established, the Leadership Programme for Serving Principals (TTA, 1998). This begins with appraisal of the principal's competency by assessors, the principal and by staff and governors of the principal's school. LPSH then concentrates on individualised development but there is central direction and control through a pre-set curriculum, centrally produced training materials, standardised assessment criteria for entrants, standardised training materials and common training for trainers.

In Greece, at the time of writing, there are no national plans to establish systematic education and training for putative, newly appointed, or long serving, principals; the majority of the school leaders today do not receive any specific training (Mavroskoufis, 1992, Papanaoum 1995, Saitis, Tsiamassi \& Chatzi 1997). They perform their role based more on their experience and intuition than on systematic training. (Saitis and Gounaropoulos, 2001, p. 87). Since the late 1990s, however, many principals have been offered optional short, in-service training courses, run by the Ministry of Education and some have chosen voluntarily to attend relevant courses provided by the National School of Public Administration. 
School leaders are selected on the basis of their seniority in the profession and not according to their managerial abilities, as two basic elements are absent: job description and job specialization (Saitis et al, 1997, 67). Since the early 1990s, dditional criteria for the selection of school leaders have been considered, such as education and training in general and training in Educational Administration and Management. The latter has a deeply legislative, rather than leadership, orientation. Teacher training includes modules relevant to educational administration and management or to the educational legislative framework, where a full description of the educational system of administration is made and issues of educational school management similar to those offered in many European countries (Lainas, 2000, p. 32).

The problem is that there is not an holistic and long term plan for the training of educational leaders. It seems reasonable to establish a National School of Educational Administration, which could coordinate the training provisions all over the country and guarantee the quality of the qualifications. Besides it is necessary to establish a new selection system and determine a clear framework of authority and responsibility (Saitis, 1997)

In Sweden, principals’ leadership preparation has been running for over twentyfive years, with some revisions from 2002 after a long period slowly adopting a new attitude to the principalship (Nygren and Johansson, 2000). Principals are educated to meet the brief national standards for principalship ${ }^{9}$ under the National Training Programme for Head-Teachers (Heimer, 1998):

The recruitment training programme for persons who want to become principals and the introduction training programme are to help new principals with practical 
administration but also to emphasise that the principal's role is as the pedagogical leader. Courses vary amongst different municipalities.

The National Principals' Training Programme is offered at universities, to all principals after about two years in office. This two-year programme comprises around thirty seminar days to deepen principals' knowledge and understanding of the national school system, the national goals for the school and the role of the school in society and the local community. It is well-funded and run by the central National Agency for Education. It is based on an holistic view of the school and its relationship with the local community. The training emphasises reflective leadership.

$>$ The continuation school leader programme is university courses for school leaders but these have not been popular.

Admission to the training takes place in consultation with the school board for the school to which the head teacher belongs. Each board is responsible for each participant being offered reasonable time for his/her own studies and adequate financial reimbursement.

The aim of the Swedish training is that head teachers should develop and use a democratic, learning and communicative form of leadership. This is similar to the emphasis placed on team work and communication skills for leaders of England's schools. Swedish training also emphasises pupils' goal achievement and development as independent learners while being able to explain and argue in support of the school's national and local government goals. The content and format of the courses will vary amongst the providing universities but will emphasise case study practice and will include some elements similar to the USA internship. 


\section{Principals' reflections on their preparation}

Our next step was to find out from interviews how principals viewed the systems outlined above. All expressed views that formal preparation was "essential and crucial" (G2) because "today’s society and parents are very well educated and they have increasing demands from their school principal to be a match for them" (C1). Only the Swede, however, had been prepared for principalship at a time when full, formal, government sponsored training had been in existence. English formal preparation experiences for the principals interviewed had been extensive but patchy and not necessarily related to management. Greek and Cypriot respondents had received virtually no formal preparation. What was noticeable overall was how few comments were made on this topic by the Swede though how to interpret this is not easy.

All the interviews took place in 2002 with the following principals.

\section{Person}

* Mr Chatzios

* Mr Georgiou

Dr Daley

Mr Lyng

Mrs Arlestig

* Mr Vassilis Ch.

* Mrs Anna P.

* Anonymity requested so names are fully or partially changed

\section{Country Identifier}

Cyprus $\quad$ C1

Cyprus $\quad$ C2

England E1

England E2

Sweden S1

Greece $\quad$ G1

Greece $\quad$ G2 


\section{Selection for principalship}

All four countries’ principals had lengthy experience as teachers, and usually as deputy principals, before promotion to headship (slightly shorter for the English principals than for those in the other countries). All had taught in several schools. G1 had been teaching for twenty-five years, almost four of these as a vice principal. G2 been working in her school for twelve years. Formerly she had been a teacher in a school abroad for Greek immigrants for five years and for another five years in a school for handicapped children. At the starting point of her career, she used to teach in a German school.One English and both Greek principals, had been appointed principal in schools in which they were already deputy, or acting, principal. All of them had continued to teach during their deputy-principalships though only one was still teaching regularly while a principal. Cypriot principals have to have served as deputies.

The value of such apprenticeship for leadership, was that I discovered that I had the capacity to think and that others responded to my ideas, Therefore I gained the confidence to move on it gave me self-belief. It was not because of training courses (E1).

The English and Swedish interviewees gained more leadership familiarity before promotion to deputy principalship than had their Greek and Cypriot counterparts because management powers are devolved and dispersed more widely in English and Swedish schools.

Our interviewees' differences became more pronounced as they proceeded to principalship. For the Cypriots, progress was: 
kind of automatic. When you had a good grade from your inspectors as a teacher, then automatically they would invite you at the Educational Service Commission to be promoted (C1).

A principal needs the right number of points:

to be on the list, you had to be high up. The first time I was number 43 out of 50 and had no chance. I was interviewed twice. The second time I was quite high on the list (C2).

Usually it is not possible to accumulate sufficient points for listing until a candidate reaches the late 50s but one of our interviewees was pleased to report his "luck at being appointed in my early fifties" (C2).

The points are still needed in Cyprus but there is no longer automatic listing; those interested must now apply for posts as is customary English practice, where applicants must meet open competition. Both our English interviewees responded to advertisements in the national, weekly, newspaper for teachers. E2, for example, was selected to be interviewed for five different jobs before finally getting a principalship.

The English schools' governing bodies interviewed and appointed them, having taken up their references and shortlisted them. Cypriot applicants too face an interview which they perceive as particularly daunting since it will be their first experience of this type of dialogue:

The interview was terrible. I was shocked. You enter a huge room.

There is nothing in it but a table and some chairs and about several people all looking at you. My interview was 25 minutes long. Some stayed for only 5 minutes. I don't know why there is a difference (C2). In England, interviews are longer than in Cyprus; candidates must also make a presentation and often take part in role plays and in-tray exercises. It will still 
be daunting but at least they will have done it before; every promotion on their career ladders requires an interview. The process can be valued because

I soon realised that ... the governors were of the same mind as me - the governors were creative as is the whole environment in this area (E1).

Thus in England, the interview enables the candidate to find out if they want to lead a particular school as well as enabling the school to find out if the candidate suits them.

Despite these differences, the questions faced by candidates sound like those experienced by applicants everywhere as these examples from Cyprus show:

The questions they asked were 'What are you going to do to have your name remembered in the school to which you are first appointed?', 'What must a principal do to have a well organised school?' (C2)

\section{Preparation for principalship}

Initially, there seemed little comfort for us as academics providing leadership education; all four countries' respondents stressed how they had learnt from experience, watching their principals and then deciding what they would emulate or avoid on becoming principals themselves:

[my] training was almost accidental. As I developed through my career I was lucky in having principals who guided me. Before becoming a teacher I was in the army education corps - which gave me a particular type of leadership and management training. [Preparation for my headship has been] mainly on the job learning (E2).

I had no training before I got the job ... I had good learning experiences ... [from] my principal ... learning how he works and thinks, how he 
controls things, how he managed things like meetings ... He ... talk[ed] to me about his inner thoughts ... Whatever I have learnt about being a principal I have learnt from him (C2).

Self-directed learning supplemented this: G2 "got used to being informed on my own" and S1 stressed that to succeed you need to take responsibility for your own learning as had C1:

I really prepared alone. Through my involvement in the unions and unionism I learnt a lot and I feel that I was prepared ... I kept reading on my own and talking and exchanging views with other colleagues and nothing else .

Both English interviewees had Masters degrees but in subjects other than management, as did one of the Greek principals who also had a nonrelated $\mathrm{PhD}$. As was common practice in Greece, neither G1 nor G2 had any formal administrative training but G1 attended one preparatory seminar on School-centered Staff Development organised by the University. G2 attended seminars too but on pedagogics. E2 "did a whole range of short management courses, such as personnel, finance, curriculum assessment" not unlike the short courses in management attended by the Cypriot respondees at the Pedgogical Institute. In contrast, E1 did "a diploma course in drama. Drama is a great boost to self esteem - it makes you feel ready to have a go [at anything]”. Cypriot principals will have gained points towards promotion through obtaining Masters degrees though, as yet, no teachers with Masters degrees in educational administration are old enough to have acquired enough other points to become principals. Swedish principals are trained after appointment. They do not have pre-service training as it is felt 
important to select people who will make good leaders before giving them principalship training.

\section{Training on the job}

The importance of this was stressed by all the respondents though there were variations for individual circumstances. For S1, " It was trial and error". Expanding on this, G1 stated that:

The passing from the role of the teacher to the role of a principal was hard ... I had to tackle my colleagues’ reluctance to [accept] the change [in] the balance of power in the school [he had been vice principal] as well as with my own doubts about how competent I was for such a duty. To increase confidence, there were various types of induction training. The English principals both had about ten days of local government provided short courses on practicalities in their first year after appointment, on "budgeting, curriculum planning, personnel, IT - even how to turn on the computer (which you don't have to do as the principal!)” (E1). Once through such induction, English principals have to agree targets each year with their governing bodies and decide on the training needed to achieve these. E2 reported how supportive his governors had been with this. Both also can acquire experiences from other principals at local conferences but "I hate those ... they are so depressing - everyone sits around moaning” (E1). Both of them had taken, or were taking, a doctorate in leadership to give themselves:

wider horizons and it helped with my stress management too...meeting with outsiders that took me out of this. It was the best way of getting me into a thinking zone - it gave me refreshment and raised my self-esteem (E1), 
while E2 was interested in "how leadership develops teaching and learning". The Swedish experience was the most extensive: "I have gone through the national program for principals and lots of shorter municipal in-service training" (S1). Leadership professional development was not all contained in external courses. During the last twenty years, the concept of the practitioner researcher has become accepted in England. E2 is developing his own work on teaching and learning for local universities' teacher training courses. This is quite common and from the late 1990s, the Department for Education and Skills began offering grants to principals to facilitate their personal studies, research visits in England and internationally and funds to disseminate outcomes.

\section{Ideas for improving preparation}

The Cypriot principals had the most suggestions for changing their training. Those from England and Sweden felt that the current alterations in their nation's programmes had already improved on the preparation they had received but S1 added that training needed to inculcate,

the need for high expectations of our followers, pupils and results ... pupils' involvement, responsibility and influence. To communicate so stakeholders understand what, how and why we do as we do.

Cypriot colleagues wanted both in-service and degree courses which should, include human relations and ways of communication with the staff and parents [because] If you don't cooperate correctly with your staff and students, then you don't have the whole picture for the school (C2). In more detail:

The principal needs to know the duties of his position, disciplinary matters, rules about personnel, rules about students, all those are the 
Alpha and the Omega of his position because he always has to face them on a daily basis. Then, he needs psychology and pedagogy, he needs to know about parents, society, correspondence with the Ministry, he needs to have public speaking skills because very often he will speak in public (C1).

\section{Conclusion}

This last comment indicates the extent to which school principals must take note of the demos of their schools, an approach fostered (and enforced) through state legislation in our countries. This aspect of democratic accountability was found in all our four systems and seemed to offer a clue towards finding a common philosophy of education leadership which we might term, 'Europeaness'. At our final seminar we considered if this had different features from American democracy.

Speaker 1: ... the USA talks about the rights people have. [In Europe] ... its about the way we will create a common society. So it's more ... collective [for us] ... in North America, it's ... individual ${ }^{10}$. Speaker 3: $\quad$... in America ... through this individual achievement there will be some 'spill over' ... into the collective good ... in most European societies it is the collective that is the prime and this [will have] 'spill over' effect for individuals ... the foundation will be democratic. Sadly, there is no space here to develop these putative ideas but readers are invited to engage the authors in further debate or to consult our CD-ROM. .

Reflecting on the issues in this article, we found that the more centralised systems had less principal preparation than the less centralised ones. We found consensus that getting the right people into principalship matters as much as how you 
train them but that even a good leader can be improved through training. All the principals had evinced concern about their lack of formal preparation but had coped through in-service training and the lessons of experience. The less preparation they had received, however, the greater appeared to be their apprehensions on taking office. 


\section{References}

Ackerman, R.H. (1998). A Conversation on The Rocks, in R. Van Der Bogert,

Making Learning Communities Work: the critical role of the leader as learner. San

Francisco: Jossey-Bass.

Brundrett, M. (1999). 'The Range of Provision of Taught Higher Degrees in

Educational Management in England and Wales', International Studies in

Educational Administration, 27 (2): 43-59.

Brundrett, M. (2001) 'The Development of School Leadership Preparation

Programmes in England and the USA; A Comparative Analysis', Educational

Management and Administration, 29 (2): 229-246.

Budge, D. (1999) ‘ There's no euro for school inspectors’, Times Educational

Supplement. Issue 4316, 19 March, p.22.

Bush, T. (1998) 'The National Professional Qualification for Headship: the Key to

Effective School Leadership?’ School Leadership and Management, 18 (3): 21-33.

Cohen, l., Manion, L. and Morrison, K. (2000) ( $5^{\text {th }}$ ed) Research Methods in

Education. London, New York:RoutledgeFalmer.

Dimmock, C. and Walker, A. (1998) 'Comparative educational administration:

Developing a cross-cultural conceptual framework', Educational Administration Quarterly. 30 (4): 558-595.

Doolittle, G., \& Barnett, B. (Eds) (2003) 'Innovative Practices in Educational Leadership Preparation:What Are We Doing and How Are We Influencing Students and Schools?' Journal of School Leadership, 13, (6).

Drake, P., Pair, C., Ross, K., Postlethwaite, T. and Ziogas, G. (1997) Appraisal Study on the Cyprus Educational System. Paris: International Institute for Educational Planning. 
Gronn, P. (1999) The Making of Educational Leaders. London:Cassell.

Gunter, H. and Ribbins, P. (2002) 'Leadership studies in education: towards a map of the field', Educational Management and Administration, 30 (4):387-416.

Heimer, J. (1998) 'Rektorsutbildningens historia och morgondagens krav’, in O.

Johansson \& L. Lindberg, (red.), Rektor en språngbräda för utveckling? Centrum för skolledarutveckling, Umeå universitet: Umeå, Sweden, s. 107-126.

Kreuger, R.A. (1998) Analyzing and reporting focus group results. Vol 1-6 Thousand Oaks, CA:Sage.

Lafond, A. (1995) 'The European dimension of educational management as seen through networking' European Journal of Education, 30 (3):317.

Lainas, A. (2000) 'Management and Work Planning of Schools: Scientific Perspectives and Greek Reality’ in Z. Papanaoum (Ed.), The Planning of Teaching Work in the School, pp. 23-40. Thessaloniki (in Greek)

Mavroskoufis, D. (1992) 'Aspects in the Issue of Evaluation, the Selection and the Role of Principals in Secondary Education', Contemporary Education, 64: 24-36 (in Greek).

Morgan, D. L. (1988) Focus Groups as Qualitative Research. Beverly Hills: Sage Nygren, A., \& Johansson, O. (2000) ‘Den svenske rektorn efter 1945 kvalifikationer, arbetsuppgifter och utmaningar', in L. Moos, S. Carney, O. Johansson, \& J. Mehlbye, J (red.), Skoleledelse i Norden - en kortlegning af skoleledernes arbejdsvilkår, rammebetingelser og opgaver. En rapport til Nordisk Ministerråd, Nord 2000:14, Köpenhamn.

Papanaoum, Z. (1995) School Management: Theoretical Analysis and Empirical Research, Thessaloniki: Kiriakidis. (in Greek) 
Pashiardis, P. (1995) 'Cyprus Principals and the Universalities of Effective

Leadership’ International Studies in Educational Administration, 23(1):16-27.

Pashiardis P. (1997) 'Towards Effectiveness: What do Secondary School Leaders in Cyprus Need?’ Journal of In-service Education, 23(2):267-282.

Pashiardis, P and Orphanou, S. (1999) ‘An Insight into Elementary Principalship in Cyprus', The International Journal of Educational Management, 13 (5):241-251.

Pashiardis, P., and Ribbins, P. (2000, September). On Cyprus: The making of Secondary School Principals. Paper presented at the conference of ACEA, CCEAM, NZEAS, PNGEA, TSPA on Education: The Global Challenge, Hobart, Tasmania, Australia.

Richmon, M. and Allison, D. (2003) 'Towards a Conceptual Framework for Leadership Enquiry’, Educational Management and Administration, 31(1): Saitis, Ch. (1997) 'The Reform of Educational Management in Greek Education, 1976-1996’, New Education, 81:109-120 (in Greek).

Saitis, Ch., Tsiamassi, F. and Chatzi, M. (1997) 'The School Director: ManagerLeader or Traditional Bureaucrat?’ New Education, 83:66-77 (in Greek).

Saitis, Ch. and Gounaropoulos, G. (2001) 'The Necessity of Planning for the Creation of Administrative Staff in Education', New Education, 99:75-89 (in Greek).

Schon, D.A. (1987) Educating the Reflective Practitioner: Towards a New Design for Teaching and Learning in the Professions. London: Jossey Bass.

TTA (Teacher Training Agency), (1997) National Standards for Principals. London:TTA.

TTA (1998) TTA National Leadership Programme for Serving Headteachers. London:TTA 
Thody, A.M. (1998) 'Training school principals, educating school governors', International Journal of Education Management, 12_(5):232-239.

Tomlinson, H., Gunter, H., \& Smith, P. (1999) Living Headship: Voices, values and vision. London: Paul Chapman.

Van den Branden, J and Lambert, J. (1999) 'Cultural issues related to transnational Open and Distance Learning in universities: A European problem?', British Journal of Educational Technology, 30(3): 251.

Woltring, C., Constantine, W., \& Schwarte, L. (2003) 'Does Leadership Training Make a Difference?’, Public Health Management in Practice, 9. CDu/UC Public Health Leadership Institute.

\section{Notes}

1 This article relates only to England. The other three constituent nations of the United Kingdom have different systems.

2 This article relates only to the Republic of Cyprus. The Turkish occupied area of Cyprus has a different system.

3 Note to be inserted after blind review completed 4 e.g. The European Free Trade Association (EFTA), the Council of Europe, the Western European Union, the Scandinavian Free Trade group.

5 Article 3 of the Treaty of Rome relating to removing obstacles to free movement of labour and commitment to raising standards of living. 
6 Additionally, $\mathrm{xxx}$, was a participant in the first two focus groups.

7 There are a few cases where principals of primary and secondary schools have come from other occupations but his is rare. The government has indicated that it would like to encourage this.

8 Each school in England and Wales has a part-elected, part appointed Governing Body (of teachers, parents, political party and community representatives, local government representatives and those chosen by the school's founding authority) to advise the head; the Body is legally the leader of the school. A Governing Body usually meets termly and usually has Committees for particular aspects of school business such as Finance or the Curriculum or Standards. Governors are responsible for setting principals' performance management targets, for their appraisals and for determining their salaries.

9 Curriculum for the Compulsory School, Lpo 94, Lpf 94.

10 The theoretical origins of these differences can be seen in the works of such writers as the American, Thomas Paine and the European Jean Jacques Rousseau. 